September 2015

\title{
The Personal Liability of Insurance Claims Adjusters for Insurance Bad Faith
}

Chad G. Marzen

Florida State University

Follow this and additional works at: https://researchrepository.wvu.edu/wvlr

Part of the Insurance Law Commons

\section{Recommended Citation}

Chad G. Marzen, The Personal Liability of Insurance Claims Adjusters for Insurance Bad Faith, 118 W. Va. L. Rev. (2015).

Available at: https://researchrepository.wvu.edu/wvlr/vol118/iss1/16

This Article is brought to you for free and open access by the WVU College of Law at The Research Repository @ WVU. It has been accepted for inclusion in West Virginia Law Review by an authorized editor of The Research Repository @ WVU. For more information, please contact ian.harmon@mail.wvu.edu. 


\title{
THE PERSONAL LIABILITY OF INSURANCE CLAIMS ADJUSTERS FOR INSURANCE BAD FAITH
}

\author{
Chad G. Marzen*
}

I. INTRODUCTION

II. REPORTED CASES ADDRESSING INSURANCE COMPANY EMPLOYEE

ADJUSTER BAD-FAITH LIABILITY

A. The Early Cases of the 1970s

B. The Questioning of the Doctrinal Rule

1. Early 1990's Cases Upholding the Doctrinal Rule ...................418

2. The O'Fallon, Garrison Contractors, and Taylor Decisions... 419

C. An Emerging Split of Authority on Adjuster Liability.

1. Courts Applying the Fraudulent Joinder Doctrine .....................424

2. Courts Declining to Apply the Fraudulent Joinder Doctrine ... 427

3. Traditional Agency Rule Relating to Contract and Tort Liability.

III. PROPOSAL FOR BAD-FAITH LIABILITY FOR INSURANCE COMPANY EMPLOYEE ADJUSTERS

\section{INTRODUCTION}

Insurance company employee claims adjusters are, in many ways, similar to detectives. Claims adjusters must fairly and honestly investigate and evaluate, in some instances, a myriad of various types of insurance claims. ${ }^{1}$ In many cases, adjusters work outside of the office, inspecting potential insured losses, ${ }^{2}$ and the hours of adjusters do not always correspond to the typical 8 a.m. to 5 p.m. workday. If a loss occurs at 7 p.m., and the evidence of that loss may be compromised by a delay, the adjuster may need to investigate an incident immediately. In addition to the typical prescribed duties of examining

* Assistant Professor of Legal Studies, Florida State University, College of BusinessDepartment of Risk Management/Insurance, Real Estate and Legal Studies. The author can be reached at cmarzen@fsu.edu.

1 Bureau of Labor Statistics, Occupational Outlook Handbook: Claims adjusters, APPRAISERS, EXAMINERS, AND INVESTIGATORS (2014-15), http://www.bls.gov/ooh/business-andfinancial/claims-adjusters-appraisers-examiners-and-investigators.htm.

2

Id. 
and adjusting claims, the adjuster may also be required to serve as an adviser of sorts to notify a claimant on the guidelines for filing and pursuing a claim. ${ }^{3}$ In essence, an adjuster has to balance the duties owed to his or her employer, the insurance company, and the duties owed to claimants as part of their insurance contract with the company.

Insurance claims adjusters today must also balance the requirements of the job with developments in the ways claims are handled and processed with the growth of new technology. In his book Delay, Deny, Defend: Why Insurance Companies Don't Pay Claims and What You Can Do About It, Professor Jay M. Feinman notes that computer technology now plays a key role in insurance claims processing. ${ }^{4}$ For instance, Professor Feinman describes the "Colossus" system, which can set an estimated value on a claim by sorting through information concerning a claimant's alleged injuries and losses and making comparisons with other results and decisions throughout a region or the country on similar claims. ${ }^{5}$ In a more technologically-driven world, even the world of insurance, apparently present since the age of the Babylonians, ${ }^{6}$ is changing.

One of the currents of change sweeping through the insurance industry is the rise of insurance bad-faith liability. While insurance companies typically are the named defendants in an insurance bad-faith lawsuit, an increasing number of writers have commented on the potential liability of individual insurance adjusters for insurance bad-faith liability. ${ }^{7}$ There is a developing

3 See Office of Mgmt. and Enter. Servs., Insurance Claims Adjuster, \#A11, OK.Gov, http://www.ok.gov/opm/jfd/a-specs/al 1.htm (last visited Oct. 8, 2015).

4 See Jay M. Feinman, Delay, Deny, Defend: Why Insurance Companies Don't Pay Claims aND What You CAN Do ABOUt IT 71-72 (2010) ("The systems control the adjusters, and the systems are driven by information technology. An industry has developed to provide computerized systems to process the mass of information that adjusters deal with; estimate the cost of repairs to damaged property; check medical expenses; evaluate personal injury claims; store and report on a claimant's history; and do everything else a claims department needs to do. Insurance companies can choose among Claims Desktop, ClaimsOffice Suite, ClaimSearch, ClaimDirector, Claims Outcome Advisor, ClaimIQ (including Medical InjurylQ and LiabilityIQ), and eClaim Manager, among others. Or they can develop their own systems.").

$5 \quad I d$. at 72 ("The immodestly named Colossus takes information about a claimant's injury, symptoms, trauma, treatment, and impairment, churns the information through more than ten thousand decision rules, measures the results against financial parameters input by the insurance company, and places a monetary value on an injured person's claim.").

6 See Insurance, THE COLUMBIA EnCYCLOPEDIA 1393-94 (Paul Lagassé ed., 6th ed. 2000); see also Aleatra P. Williams, Insurers' Rights of Subrogation Against Tenants: The Begotten Union Between Equity and Her Beloved, 55 DRAKE L. REV. 541, 568 (2007).

7 See James I. Devitt \& Robert C. Hastie, Independent Insurance Adjusters Liable for Bad Faith: Fair or Farce?, 14 W. ST. U. L. REV. 229 (1987); Douglas R. Richmond, The Extent of Good Faith: Insureds Versus Claims Professionals, 30 INs. LITIG. ReP. 497 (Aug. 25, 2008); Jeffrey W. Stempel, The "Other" Intermediaries: The Increasingly Anachronistic Immunity of Managing General Agents and Independent Claims Adjusters, 15 CoNN. INS. L.J. 599 (2009). 
legal question today as to whether the individual employee adjusters of insurance companies can be subject to insurance bad-faith liability, and a variance of rulings on the issue has resulted over the years.

This Article examines the question of whether employee adjusters of insurance companies, not independent adjusters, outside adjusters, or thirdparty administrators, ${ }^{8}$ can and should be held liable for insurance bad-faith liability. A general doctrinal rule developed among early reported cases which precluded personal bad-faith liability against employee adjusters up until 1993. However, in 1993, the landscape started to change with a Montana Supreme Court decision in O'Fallon $v$. Farmers Insurance Exchange, ${ }^{9}$ which held that a third-party could recover on a statutory bad-faith theory for the alleged badfaith adjustment of a third-party claim. ${ }^{10}$ This decision soon expanded to firstparty cases with the 1998 decision of the Texas Supreme Court in Liberty Mutual Insurance Co. v. Garrison Contractors, Inc. ${ }^{11}$ and in 2003 with the landmark decision of the West Virginia Supreme Court in Taylor v. Nationwide Mutual Insurance Co. ${ }^{12}$

The O'Fallon, Garrison Contractors, and Taylor decisions have left courts throughout the country with some degree of uncertainty concerning personal liability issues in the past two decades. A growing number of courts have questioned the general doctrinal rule which bars personal liability for bad faith, and personal liability issues for employee adjusters are far from settled.

Part II of this Article discusses significant reported cases to date which both uphold the general doctrinal rule as well as challenge it. As the case law on this issue has progressed, a split of authority has emerged on whether or not insurance company employee claims adjusters can be subject to personal liability for bad faith.

As Professor Feinman contends, adjusters today have less discretion over handling claims than in prior decades. ${ }^{13}$ With less discretion, consequently, it follows that there should also be fewer instances where an employee adjuster acts in such a manner that is egregious and purposefully prejudicial toward an insured. Despite what follows intuitively from less discretion, there are still many cases throughout the country today where insurance company adjusters are named as defendants in insurance bad-faith lawsuits.

This Article focuses on employee adjusters of insurance companies. The issue of personal bad-faith liability of independent claims adjusters, managing general agents, and third-party administrators is not intended to be addressed in this Article. For these issues, see generally Devitt \& Hastie, supra note 7; Richmond, supra note 7; Stempel, supra note 7.

$9 \quad 859$ P.2d 1008 (Mont. 1993).

$10 \quad$ Id. at 1015.

11966 S.W.2d 482, 487 (Tex. 1998).

12589 S.E.2d 55, 62 (W. Va. 2003).

13 See FEINMAN, supra note 4, at 70-74. 
This Article proposes a uniform standard in Part III that courts can employ in cases where insureds allege insurance company employee adjusters act in bad faith. To keep insurance company employee adjusters fair and honest and to ensure the quasi-fiduciary nature of the insurance contract ${ }^{14}$ is upheld, this Article contends that insurance company employee adjusters be held liable for insurance bad faith in cases where a trial court makes an evidentiary finding that an employee adjuster acts with the purposeful or actual malicious intention (not knowing, reckless, or negligent intention) to prejudice the rights of an insured.

\section{REPORTED CASES ADDRESSING INSURANCE COMPANY EMPLOYEE ADJUSTER BAD-FAITH LIABILITY}

As a number of commentators have noted, insurance bad faith grew out of the contractual duty of good faith and fair dealing found in contracts. ${ }^{15}$ The early third-party ${ }^{16}$ and first-party insurance ${ }^{17}$ bad-faith cases dealt primarily

14 See Hazel Beh \& Jeffrey W. Stempel, Misclassifying the Insurance Policy: The Unforced Errors of Unilateral Contract Characterization, 32 CARDOzo L. REv. 85, 109 (2010) ("[A]s contrasted to typical contract relations, the law generally views the insurer-policyholder relationship as somewhat fiduciary in nature (for most first-party insurance) or even fully fiduciary (for liability insurance where the insurer is charged with defending and settling claims).").

is See, e.g., Constance A. Anastopoulo, Bad Faith: Building a House of Straw, Sticks, or Bricks, 42 U. MEM. L. REV. 687, 695 (2012); Chad G. Marzen, Can (and Should) an Insurance Defense Attorney Be Held Liable for Insurance Bad Faith?, 7 VA. L. \& Bus. REv. 97, 122 n.150 (2012); Marc S. Mayerson, "First Party" Insurance Bad Faith Claims: Mooring Procedure to Substance, 38 TORT TRIAL \& INS. PRAC. L.J. 861, 864 (2003); Douglas R. Richmond, Bad Insurance Bad Faith Law, 39 TORT TRIAL \& INS. PRAC. L.J. 1, 3-4 (2003).

16 See Randy Maniloff \& JefFrey Stempel, General Liability InSURANCE Coverage: KEY ISSUES IN EVERY STATE 533 (2d ed. 2012) (noting that the origins of the third-party insurance bad-faith claim dates back to the Court of Appeals of New York decision in Brassil v. Maryland Cas. Co., 104 N.E. 622 (N.Y. 1914)).

Bad faith claims, like types of insurance, fall into two general categories: third-party and first-party. Only liability insurance is truly third-party insurance. Liability insurance is described as third-party insurance because the interests protected by the policy are ultimately those of strangers to the contract who are injured by the insured's conduct. The earliest insurance bad faith cases arose in the third-party context.

Douglas R. Richmond, An Overview of Insurance Bad Faith Law and Litigation, 25 SETON HALL L. REV. 74, 80 (1994).

17 See MANILOFF \& STEMPEL, supra note 16 (remarking that the origins of the cause of action for first-party insurance bad faith are found in the California Supreme Court decision of Gruenberg v. Aetna Ins. Co., 510 P.2d 1032, 1037 (Cal. 1973)). "First-party bad faith arises when the insurer wrongfully refuses to settle a valid claim with the policyholder under his contract." Cassandra Feeney, Note, Are You "In Good Hands"? Balancing Protection for Insurers and Insured in First-Party Bad-Faith Claims With a Uniform Standard, 45 NEW ENG. L. REV. 685, 691 (2011). 
with the issue of imposing bad-faith liability upon insurers. As courts began to examine the issue of insurer liability for insurance bad faith, litigators attempted to expand liability to entities outside of insurance companies, including claim adjusters and even attorneys. ${ }^{18}$ Even the California Supreme Court in Gruenberg v. Aetna Insurance Co., ${ }^{19}$ the decision that is credited with recognizing a cause of action for first-party insurance bad faith, examined the potential liability of an insurance adjusting firm and an insurance law firm. The emergence of insurance bad faith would bring forth many questions concerning the liability of insurance company employee claims adjusters.

\section{A. The Early Cases of the 1970s}

The early reported cases of the 1970s involving insurance bad faith generally rejected the notion of imposing insurance bad-faith liability upon employee claims adjusters. While the case did not involve an employee claim adjuster, but rather the alleged actions of independent adjusters, in 1970 the Pennsylvania Supreme Court in Hudock v. Donegal Mutual Insurance Co. ${ }^{20}$ held that insurance adjusters could not be liable for insurance bad faith because the plaintiffs did not prove the independent adjusters had a contractual relationship with the insureds. ${ }^{21}$ Similarly, the California Supreme Court in Gruenberg, the decision recognizing first-party bad faith, declined to extend bad-faith liability to independent claims adjusters. ${ }^{22}$

18

21

22

See generally Marzen, supra note 15.

510 P.2d 1032, 1038-39 (Cal. 1973).

264 A.2d 668, 672 (Pa. 1970). The Pennsylvania Supreme Court stated:

The basic defect in these allegations, as noted by the court below, is the failure to establish a contractual relationship between the adjusters and the insured appellants. Without such a relationship, it is impossible for the adjusters to be liable for breach of contract to the insureds. If the adjusters had been acting within the scope of their authority, their alleged failure to perform their principals' contractual duties which had been delegated to them could be attributed to the principals, thereby rendering the insurance companies liable for breach of contract. But actions by the adjusters beyond the scope of their authority could not result in the imposition upon them of contractual duties to the appellants which they had never assumed. The adjusters had a duty to their principals, the insurance companies, to perform whatever tasks were assigned to them, but this duty to did not serve to create a contractual obligation between the adjusters and appellants.

Id.

Gruenberg, 510 P.2d at 1038-39. The California Supreme Court noted:

Plaintiff contends that these non-insurer defendants breached only the duty of good faith and fair dealing; therefore, we need not consider the possibility that they may have committed another tort in their respective capacities as total strangers to the contracts of insurance. Obviously, the non-insurer defendants were not parties to the agreements for insurance; therefore, they are not, as such, subject to an implied duty of good faith and fair dealing. 
The general doctrinal rule immunizing outside claims adjusters from liability for insurance bad faith on privity of contract grounds soon extended to insurance company employee adjusters. The California appellate courts took the lead in developing this rule. In Iversen v. Superior Court of Los Angeles County, ${ }^{23}$ the California Court of Appeals Second District extended the immunity rule in the context of third-party insurance case. ${ }^{24}$ In Iversen, an insured filed a lawsuit alleging an insurer and insurance claim supervisor breached the duty of good faith and fair dealing in allegedly failing to accept a settlement offer within policy limits in an underlying indemnification case. ${ }^{25}$ In response to the complaint, the claims supervisor filed an evidentiary declaration attached to a motion for summary judgment in which he noted he was not a party to any contract with the insured and that he had no role in the selling or underwriting of any insurance contract at issue in the case. ${ }^{26}$ As an evidentiary matter, the plaintiff filed no response affidavits or written evidence indicating the claims supervisor committed any act of bad faith. ${ }^{27}$ However, the trial court denied the claims supervisor's motion for summary judgment. ${ }^{28}$

On a review by writ of mandate, the California Court of Appeals reversed the trial court's denial of the motion for summary judgment. ${ }^{29}$ In overturning the trial court, the California Court of Appeals reasoned that any duty owed by the claims supervisor to the insured would necessarily depend upon a "contractual relationship," and because he was "an agent of the insurer and not a party to the contract of insurance, he is not bound by the implied covenant and owes no duty to the insured not to breach it., ${ }^{, 30}$

Just over three years following the Iversen decision, the California Supreme Court extended the rule precluding personal liability for insurance bad faith for insurance company "managerial employees" in a first-party insurance case in the 1979 decision of Egan v. Mutual of Omaha Insurance Co. ${ }^{31}$ The underlying facts of the Egan case involved allegations of first-party bad faith relating to an alleged contractual breach, failure on the part of an insurance company and its agents to properly investigate a disability insurance claim. ${ }^{32}$ The plaintiff specifically alleged that an insurance company and two

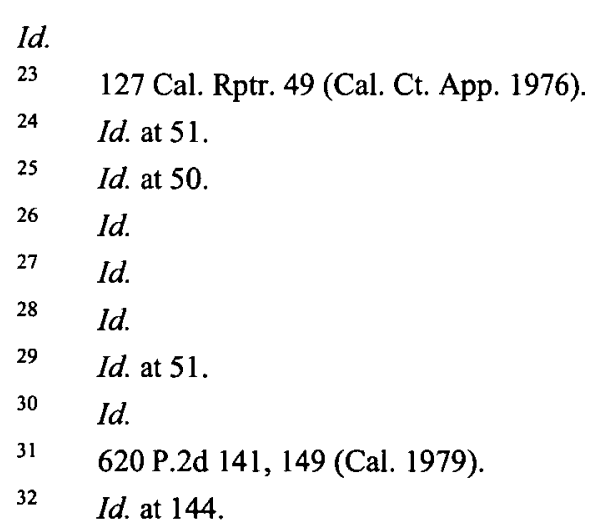


managerial employees of the company failed to permit the plaintiff to be seen by a doctor of his choice and also failed to properly investigate his disability insurance claim by consulting with his treating physicians. ${ }^{33}$ At the trial court level, the court not only assessed an award of $\$ 45,600$ in general damages, $\$ 78,000$ in emotional distress, and $\$ 5,000,000$ in punitive damages against the insurer, but also general damages of $\$ 1,000$ and punitive damages of $\$ 500$ against the agency claims manager involved in the case and $\$ 500$ in general damages and $\$ 400$ in punitive damages against an agency claims adjuster. ${ }^{34}$

The California Supreme Court reversed the punitive damages award against the insurer. ${ }^{35}$ Significantly, the California Supreme Court also examined the issue of liability of the two managerial employees. The Supreme Court held that because the two managerial employees acted as agents for the insurer, they were "not parties to the insurance contract and not subject to the implied covenant." ${ }^{36}$ In arriving at this conclusion, the California Supreme Court cited its own rationale in the Gruenberg decision, where it declined to extend personal bad-faith liability to independent claims adjusters. ${ }^{37}$

Thus, in all of these cases, the California appellate courts not only took a lead in developing a doctrinal rule shielding insurance company employees from insurance bad-faith liability, but applied it both in the contexts of firstparty claims involving alleged breaches of the duty of good faith and fair dealing, as well as allegations of failure to accept settlement offers within policy limits. As time shifted to the 1990 s, while a number of courts continued to uphold this doctrinal rule, the first signs of questioning this rule became evident in key decisions of the state supreme courts of Montana, Texas, and West Virginia.

\section{B. The Questioning of the Doctrinal Rule}

During the early cases of the 1970 s and 1980 s, involving the emerging tort of insurance bad faith, courts largely declined to extend the contours of bad-faith liability to insurance company employee adjusters. But as is the case with many legal rules and doctrines, over time some legal rules are challenged. In 1993, a key decision in Montana changed the landscape of the rules concerning insurance company employee adjuster liability for bad faith. The Supreme Courts of Texas and West Virginia followed thereafter, leaving a divide on this significant question of insurance bad-faith liability.

$\begin{array}{ll}33 & I d . \\ 34 & I d . \\ 35 & I d . \text { at } 149 . \\ 36 & I d . \\ 37 & I d .\end{array}$




\section{Early 1990's Cases Upholding the Doctrinal Rule}

In the early 1990s, courts generally upheld the emerging doctrinal rule which did not recognize a cause of action against employee adjusters for insurance bad faith. The 1992 Indiana Court of Appeals case of Troxell $v$. American States Insurance Co. ${ }^{38}$ involved allegations of first-party bad faith surrounding a claim under a fire insurance policy. ${ }^{39}$ In Troxell, the insureds alleged the claims adjuster of the insurer committed acts of first-party insurance bad faith in failing to negotiate a settlement of the claim. ${ }^{40}$ While the Indiana Court of Appeals upheld the trial court's entry of summary judgment for the claims adjuster, insurer, and two other defendants due to a contractual limitation clause, ${ }^{41}$ the court also affirmed the trial court's reasoning for granting summary judgment in favor of the claims adjuster on the basis that the adjuster had no duty to represent the interests of the insured. ${ }^{42}$

Similarly, the United States District Court for the Southern District of Mississippi, interpreting Mississippi law, found an insurance bad-faith action could not lie against adjusters in the Ironworks Unlimited $v$. Purvis ${ }^{43}$ first-party insurance case in $1992 .{ }^{44}$ The Ironworks Unlimited case presented an issue that has appeared in a number of subsequent reported bad-faith cases involving insurance company employee adjusters: whether or not the joinder of an insurance company employee adjuster is fraudulent for the purposes of defeating removal to the federal courts. For diversity jurisdiction to exist in federal courts, more than $\$ 75,000$ must be in controversy in the case and complete diversity of plaintiffs and defendants must occur. ${ }^{45}$ If diversity jurisdiction is broken, removal to federal court can be defeated. ${ }^{46}$

The plaintiff in Ironworks Unlimited proffered allegations of bad faith against an insurer, as well as an insurance company claims representative, and filed its complaint in state court. ${ }^{47}$ The defendants filed a notice of removal and contended that the insurance company claims representative was joined fraudulently to defeat diversity jurisdiction. ${ }^{48}$ In analyzing the facts of the case,

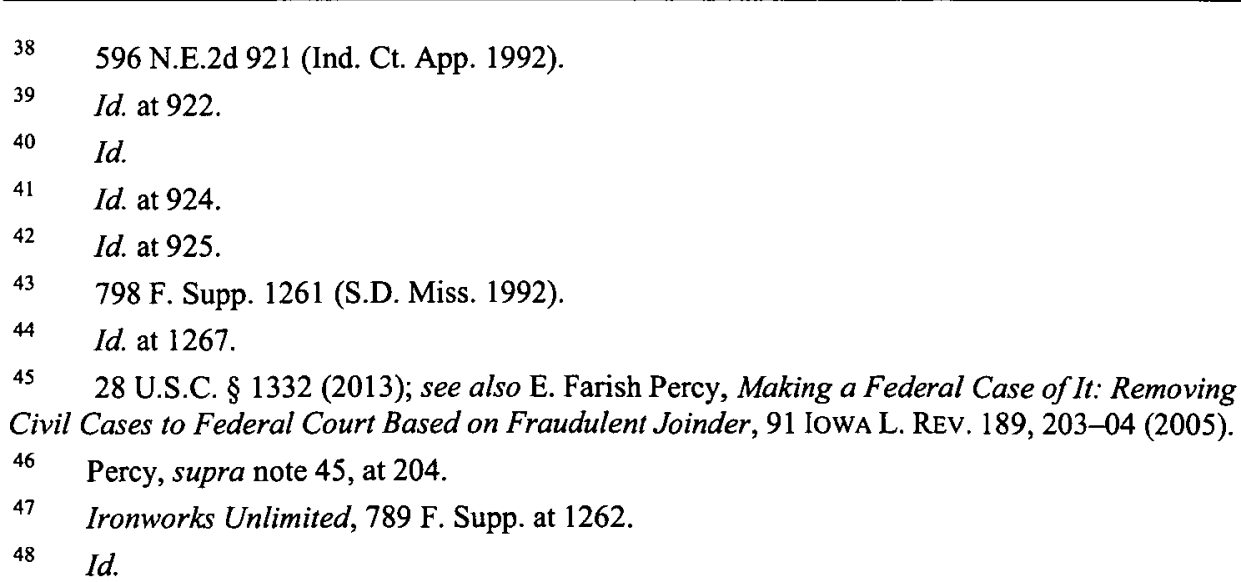


the court found that none of the plaintiff's allegations related to adjustment of the claim, only to the denial of the claim. ${ }^{49}$ Because no evidence indicated the claims representative was a party to the contract, the court upheld a magistrate judge's ruling that the claims representative was fraudulently joined to the case. ${ }^{50}$ By 1993, it appeared that insurance company employee claims adjusters and representatives would never be held personally liable for insurance bad faith. But the rule would not remain impenetrable.

\section{The O'Fallon, Garrison Contractors, and Taylor Decisions}

Although courts essentially rejected a direct cause of action for insurance bad faith against insurance company employee adjusters and representatives up until 1993, a groundbreaking decision of the Montana Supreme Court in $O^{\prime}$ Fallon v. Farmers Insurance Exchange ${ }^{51}$ opened the doors to the possibility of insurance employee adjusters being held liable for common-law claims based on statutory violations in the third-party insurance context. In $O^{\prime}$ Fallon, the plaintiffs were a driver and passenger reportedly stopped at a red light at an intersection in Missoula, Montana. ${ }^{52}$ As they were stopped, another vehicle operated by an allegedly intoxicated individual struck the car, causing physical injuries to the plaintiffs. ${ }^{53}$ After the plaintiffs filed a liability claim against the alleged tortfeasor, the alleged tortfeasor filed a counterclaim against the driver reportedly stopped at the intersection. ${ }^{54}$ In response, the plaintiffs alleged that the activities of the insurer and claims agent in filing the counterclaim and in the underlying case constituted a violation of the Montana Unfair Trade Practices Act in allegedly failing to settle the claims after the issue of liability had become reasonably clear. ${ }^{55}$

In particular, the Montana Supreme Court comprehensively discussed the personal liability issues relating to the claims agent in the case. On appeal, the claims agent argued that because he was not an "insurer," he could not be subject to liability under the statute. ${ }^{56}$ In analyzing the text of the statute, the court noted that "no person" can violate the Unfair Trade Practices Act's provisions relating to unfair claims settlement. ${ }^{57}$ Parallel to the O'Fallon

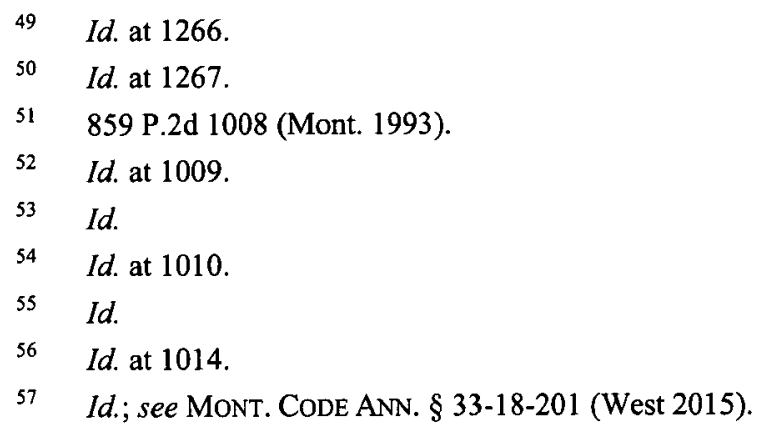


decision ${ }^{58}$ based on the Unfair Trade Practices Act, Montana's insurance law defines a "person" not only as an "insurer" or "company" but also as an "individual." ${ }^{59}$ Analyzing the legislative history behind the statute, the court found that the unfair claims settlement statute did not conflict with a statutory cause of action for insureds and third-party claimants provided for in another provision of Montana law ${ }^{60}$ that applied only to insurance companies. ${ }^{61}$ Significantly, the Montana Supreme Court not only found that an individual could bring a third-party claim against an insurance company employee adjuster for bad faith, but that it is a common-law action based upon statutory duties, not simply a statutory cause of action. ${ }^{6}$

The Texas Supreme Court followed the lead of $O^{\prime} F a l l o n$ in holding that employee adjusters could be personally liable for alleged bad-faith misconduct in the Liberty Mutual Insurance Co. v. Garrison Contractors ${ }^{63}$ decision in 1998. In the Garrison Contractors case, the plaintiff had purchased a multi-line insurance policy from an insurer through the assistance of an employee-agent of the insurer. ${ }^{64}$ The particular policy in question had a retrospective premium feature to it, which apparently created confusion concerning the amount of premium the insured owed under the policy. ${ }^{65}$ The insured filed a third-party claim against the employee-agent for both common law insurance bad faith and statutory violations under the Texas Deceptive Trade Practices Act when a dispute arose concerning premiums due under the policy. ${ }^{66}$

A key provision of the Texas Deceptive Trade Practices Act, in effect at the time of the decision, prohibited a "person" from engaging in deceptive trade practices in the business of insurance. ${ }^{67}$ Similar to the Montana statute at issue in the $O^{\prime}$ Fallon decision, the statute in the Garrett Contractors case defined "person" to include "any individual." ${ }^{68}$ Following the lead of the Montana Supreme Court in $O^{\prime} F a l l o n$, endorsing personal liability of insurance

\footnotetext{
$58 \quad O^{\prime} F a l l o n, 859$ P.2d at 1014.

59 Mont. CODE ANN. § 33-1-202(3) (West 2015).

60 Mont. Code ANN. \& 33-18-242 (West 2015).

$61 \quad$ O'Fallon, 859 P.2d at 1015.

$62 \quad I d$.

63966 S.W.2d 482 (Tex. 1998).

$64 \quad$ Id. at 483 .

65 Id. The Court described the retrospective premium feature as follows: "The policy featured a retrospective premium plan, in which a base premium is paid, then adjusted based on actual losses. If losses are less than expected, the insurer refunds part of the base premium. If losses are greater than expected, the insured owes additional premiums." Id.

66 Id. at $483-84$.

$67 \quad$ Id. at 484

$68 \quad$ Id.
} 
company employee adjusters, the Texas Supreme Court in Garrison Contractors held that a statutory cause of action exists against an employeeagent of an insurer for bad-faith practices. ${ }^{69}$ However, in comparison with the O'Fallon decision, the Texas Supreme Court in Garrison Contractors qualified that only those employees of an insurance company who were involved in the "business of insurance" could be held liable. ${ }^{70}$ In this particular case, the Texas Supreme Court noted that the employee-agent of the insurer solicited the sale of the insurance policy at issue and was responsible for explaining insurance policy terms. ${ }^{71}$ But unlike a common-law-based cause of action in $O$ 'Fallon, the Texas Supreme Court in Garrison Contractors endorsed a statutory-based remedy.

Jointly, the decisions in O'Fallon and Garrison Contractors marked the beginning of a potential shift relating to insurance company employee adjuster liability. These two cases have started a movement in which at least one other court, the West Virginia Supreme Court, has expressed an openness to holding employee adjusters personally liable in some situations.

In 2003, the West Virginia Supreme Court followed the lead of the Supreme Courts of the states of Montana and Texas in challenging the doctrinal rule that employee insurance adjusters are immune from personal liability for alleged insurance bad-faith conduct. Similar to the Texas Supreme Court's holding in the Garrison Contractors case, the West Virginia Supreme Court held in Taylor v. Nationwide Mutual Insurance Co. ${ }^{72}$ that an insurance employee claim adjuster could be liable for statutory insurance bad-faith practices under the scope of the West Virginia Unfair Trade Practices Act. ${ }^{73}$

The underlying facts of Taylor involved a plaintiff who was injured in an automobile accident where the other driver was at fault. ${ }^{74}$ After settling for the policy limits with the tortfeasor's insurer, the plaintiff filed an underinsured motorists coverage claim ${ }^{75}$ on his own insurer's policy. ${ }^{76}$ The plaintiff contended that his insurer failed to provide an opportunity to purchase additional limits of underinsured motorist liability coverage beyond those the insurer claimed, an alleged violation of which would be contrary to West

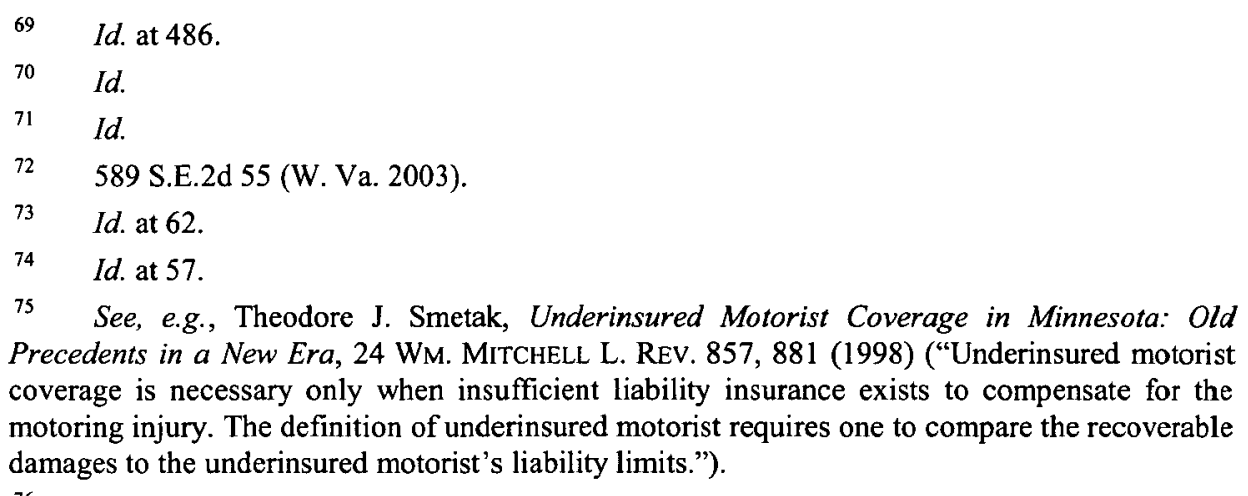

Taylor, 589 S.E.2d at 57. 
Virginia law. ${ }^{77}$ A dispute arose as to whether a nationwide mailing sent by the insurer constituted a waiver of the notice of an opportunity to purchase additional limits of coverage. ${ }^{78}$ The claims adjuster sent a letter to the insured stating, in essence, it was the insurer's position that the waiver was effective. ${ }^{79}$ In response, the insured proffered claims of breach of fiduciary duty, breach of contract, bad faith, and unfair claims settlement practices against the insurer, as well as claims of unfair claims settlement practices against the claims representative. $^{80}$

Comparable to the statutes in Montana and Texas in the $O^{\prime} F$ allon and Garrison Contractor cases, the language of the West Virginia Unfair Trade Practices Act prohibited any "person" from engaging in an unfair method of competition or an unfair and deceptive act of practice. ${ }^{81}$ The statute defined "person" to include "any individual," just like the Texas statute at issue in the Garrison Contractors case. ${ }^{82}$

In analyzing the statutory language, the West Virginia Supreme Court held that the statute's definition of "person" clearly and unambiguously expressed the intent of the West Virginia legislature to include "any individual" as encompassed within the purview of the West Virginia Unfair Trade Practices Act. ${ }^{83}$ The court noted that an "individual" could include a claims adjuster, and thus claims adjusters employed by an insurer can incur personal liability for statutory bad-faith violations of the West Virginia Unfair Trade Practices Act if they were in the "business of insurance." 84

In holding that claims adjusters can incur statutory bad-faith liability, the court rejected two arguments of the insurer and claims adjuster which were arguments which had been accepted by courts which follow the traditional rule of rejecting adjuster personal liability. First, the court did not adopt the reasoning of other courts which rejected personal liability on the basis that the claims adjuster is not a party to the actual contract of insurance between the insured and insurer. ${ }^{85}$ The court also did not accept the arguments that "fundamental principles of agency law" would reject personal liability. ${ }^{86}$ In supporting its decision, the court cited the observation that both arguments are

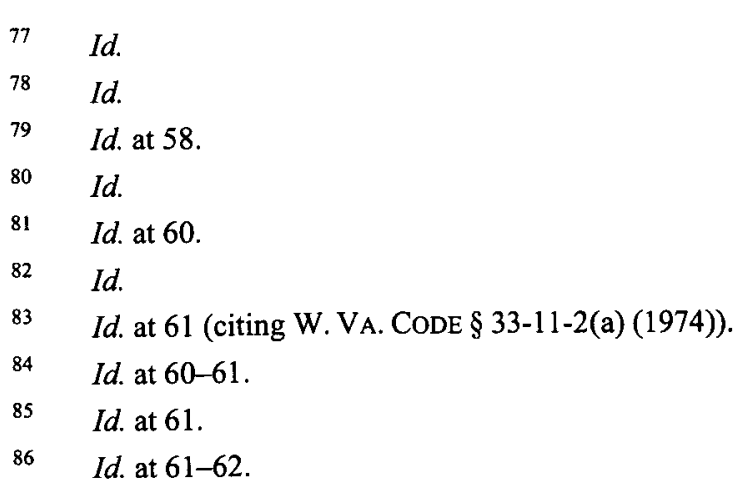


inapplicable as the personal liability of a claims adjuster is created by statute as an independent duty. ${ }^{87}$

Viewing all three decisions (O'Fallon, Garrison Contractors, and Taylor) together, there is an emerging split of authority on the liability of insurance claims adjusters and representatives for insurance bad faith. In approximately the past decade, a number of state and federal courts have examined personal liability issues and have come to varied results, and the personal liability of an insurance company claims adjuster employee for bad faith is emerging as an unsettled issue of insurance law nationwide.

\section{An Emerging Split of Authority on Adjuster Liability}

Many of the reported cases involving personal liability issues of insurance company employee adjusters and claims representatives today involve situations where an insurance adjuster or claims representative is added as a party defendant by a plaintiff to a case in attempts to defeat federal diversity jurisdiction. The resolution of cases as to whether an insurance company employee adjuster is fraudulently joined to defeat diversity jurisdiction provides a glimpse as to how a court may rule upon finding whether an insurance company employee adjuster can be held liable for insurance bad faith. Just as the courts are now divided on the overarching issue of whether to apply personal liability for bad faith to an insurance company employee adjuster, courts are also divided on the issue of the application of the fraudulent joinder doctrine. ${ }^{88}$

As a general rule, federal courts in the United States have diversity of citizenship jurisdiction when there are diverse parties and the amount in controversy exceeds $\$ 75,000 .^{89}$ If a lawsuit is filed in state court, a defendant has the right to remove the case to federal court if the elements of diversity of citizenship jurisdiction are met. ${ }^{90}$ If diversity of citizenship is lacking and the case is in federal court under diversity of citizenship jurisdiction, then the plaintiff has the right to remand the case back to state court. ${ }^{91}$ Federal law provides that courts can either deny or permit joinder in the situations where a plaintiff seeks to join additional defendants where joinder would destroy

\footnotetext{
87 Id.

88 See Matthew J. Richardson, Clarifying and Limiting Fraudulent Joinder, 58 FLA. L. REV. 119,133 (2006) ("The removing defendant may show fraudulent joinder in one of two ways, either by (1) showing that the plaintiff has falsely or fraudulently pled the jurisdictional facts of the citizenship of the parties in the complaint, often a nearly impossible task, or (2) showing that the plaintiff has no possibility of recovery against the diverse or nondiverse defendants in state court.").

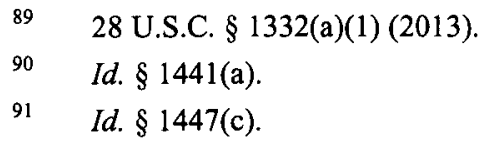


diversity of citizenship. ${ }^{92}$ However, a defendant may defeat a plaintiff's attempts to remand a case back to state court through joinder if the joinder is fraudulent. ${ }^{93}$ Courts have had diverse rulings on the fraudulent joinder issue in cases where a plaintiff seeks to add an insurance claims adjuster or representative who is an employee of the insurer as a defendant.

\section{Courts Applying the Fraudulent Joinder Doctrine}

Some courts hold that the fraudulent joinder doctrine applies for the reason that individual insurance adjusters and claims representatives are not parties to the contract of insurance between an insurance company and its insured. For instance, the case of Tipton v. Nationwide Mutual Fire Insurance $\mathrm{Co}^{94}$ involved an insurer's denial of a content coverage claim of an insured following a fire. ${ }^{95}$ The plaintiff attempted to add the insurer's property adjuster as a defendant to the lawsuit, which alleged a bad-faith denial of the claim. ${ }^{96}$ In essence, the plaintiff alleged the property adjuster was not immune from personal liability because he allegedly was a participant in a conspiracy with the insurer to deny the claim. ${ }^{97}$

In holding the fraudulent joinder doctrine applied to prevent the addition of the adjuster as a party, the United States District Court for the Southern District of Mississippi not only cited the principle that a corporation cannot conspire with an agent (property adjuster) of a corporation (insurer), but that an adjuster is not a party to the contract of insurance and the adjuster has no duty to provide coverage. 98

Similarly, in 2006, the United States District Court for the Northern District of Florida also cited the principle that a claims adjuster is not a party to a contract between an insurer and its insured. The case of Stallworth $v$. Hartford Insurance Co ${ }^{99}$ involved allegations that an insurer acted in bad faith

$92 \quad 28$ U.S.C. $\S 1447$ (e) (2013) ("If after removal the plaintiff seeks to join additional defendants whose joinder would destroy subject matter jurisdiction, the court may deny joinder, or permit joinder and remand the action to the State court.").

93 See generally Richardson, supra note 88.

$94 \quad 381$ F. Supp. 2d 567 (S.D. Miss. 2003).

$95 \quad$ Id. at $569-70$.

$96 \quad$ Id. at 570.

$97 \quad$ Id. at $570-71$.

98 Id. ("In addition, any individual, including an agent may not be held directly liable under an insurance contract if that person was not a party to the insurance contract itself, because that person has no duty arising from the policy to provide coverage. The claim involved herein is based on a contract of insurance between [the plaintiff] and [the insurer]; [the property adjuster] was not a party to that contract nor the party to look to for payment of insurance benefits." (citations omitted)).

99 No. 3:06cv89/MCR/EMT, 2006 WL 2711597 (N.D. Fla. Sept. 19, 2006). 
in denying benefits under an automobile liability insurance policy following an accident. ${ }^{100}$ The lawsuit proffered claims of breach of warranty, breach of the warranty of good faith and fair dealing, and finally unfair claims settlement practices following the claims denial. ${ }^{101}$

It appears that the plaintiffs in the case mischaracterized the allegations of breach of the warranty of good faith and fair dealing, as well as a common law claim for unfair claims settlement practices to apply to the alleged bad-faith claims. ${ }^{102}$ In Florida, bad-faith claims are covered under a statutory cause of action. ${ }^{103}$ Irrespective of the nature of the allegations, the court dismissed them because it noted that contractual liability must be resolved as a prerequisite to a bad-faith claim. ${ }^{104}$ In addition, the claims for breach of contract and breach of the implied covenant of good faith and fair dealing were also dismissed due to the lack of privity of contract between the claims adjuster and the insured. ${ }^{105}$ The court noted that dismissal of the claims adjuster would be appropriate even if the alleged conduct were "egregious" in nature. ${ }^{106}$

In addition, the Ohio Ninth District Court of Appeals also endorsed the traditional view of insurance adjuster personal liability on the privity of contract rationale in the Baker $v$. Nationwide Mutual $^{107}$ case. The court stated "[a]n individual insurance adjuster does not have a contractual relationship with a policyholder and, consequently, does not have a corresponding personal duty to act in good faith." 108 The court cited approvingly ${ }^{109}$ of the language of an Ohio Eighth District Court of Appeals case, Johnson v. State Farm Insurance Co. ${ }^{110}$ in which the court stated in a case involving personal liability for negligence of an insurance adjuster that, under Ohio law, "there is no duty owed by an insurance adjuster, in his individual capacity, to a person making a claim on their policy of insurance." 11

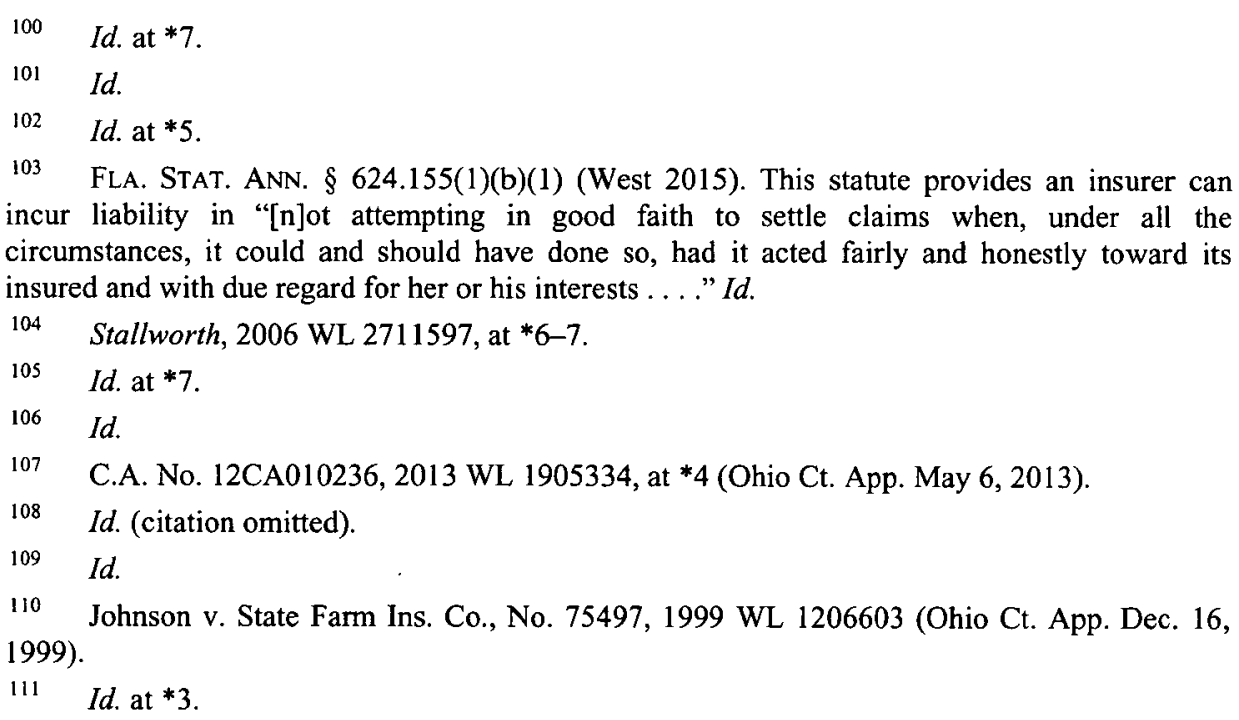


Also, in Fulkerson v. State Farm Mutual Automobile Insurance Co., ${ }^{112}$ the United States District Court for the Western District of Kentucky not only reaffirmed the rule of adjuster personal liability immunity adopted in some decisions, but the rationale of the court stands in direct contrast to the decisions in the O'Fallon, Garrison Contractors, and Taylor decisions. ${ }^{113}$ The Fulkerson case arose out of an accident where the plaintiff's underinsured motorist claim was eventually settled with the underinsured motorist's insurance carrier. ${ }^{114}$ However, approximately a year after the settlement, a common law bad-faith claim, as well as claims alleging violations of the Kentucky Consumer Protection Act and the Kentucky Unfair Claims Settlement Practices Act, were filed against the insurer in the case. ${ }^{115}$ The plaintiff not only proffered claims against the insurer in the case, but also sought to request leave for the filing of an amended complaint to add an insurer's team manager (individual employee) as a party defendant to the case. ${ }^{116}$

In Kentucky, a remedy for bad-faith misconduct of an insurer can be found in the Kentucky Unfair Claims Settlement Practices Act. ${ }^{117}$ The statute, similar to the ones at issue in the O'Fallon, Garrison Contractors, and Taylor cases, provides that any "person" may be liable for certain delineated unfair claims settlement practices. ${ }^{118}$ The Fulkerson court, in contrast to the O'Fallon, Garrison Contractors, and Taylor cases, found that it would be likely the Kentucky Supreme Court would reject any claim to hold an adjuster personally liable for bad faith. ${ }^{119}$ In finding that a claims adjuster is not "in the business of insurance," the Fulkerson court cited ${ }^{120}$ the Kentucky Supreme Court's 2000 decision in Davidson v. American Freightways, Inc., ${ }^{121}$ in which it ruled a selfinsured motor carrier was not a "person" subject to the provisions of the Kentucky Unfair Claims Settlement Practices Act. ${ }^{122}$ In Davidson, the Kentucky Supreme Court stated "[a]bsent a contractual obligation, there simply is no bad-faith cause of action, either at common law or by statute."123 Given there was apparently no contractual obligation between the claims adjuster and the insured in the Fulkerson case, the Fulkerson court held that the proposed

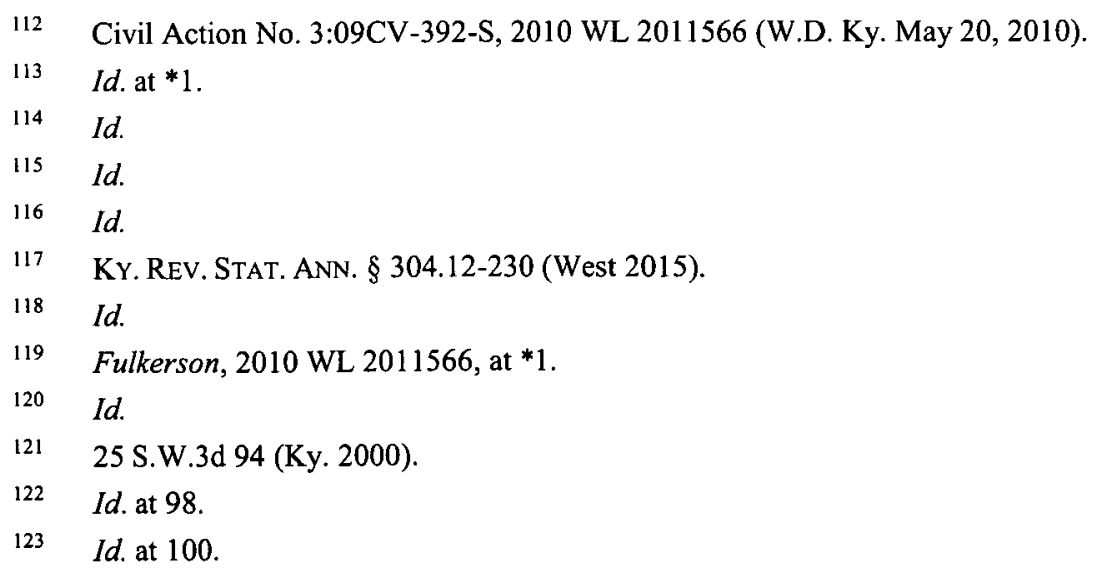


amended complaint did not state a cognizable cause of action against the adjuster. $^{124}$

\section{Courts Declining to Apply the Fraudulent Joinder Doctrine}

Although a number of courts have ruled that the fraudulent joinder doctrine applies in instances where a plaintiff attempts to add a claims adjuster defendant to remove diversity jurisdiction, a growing number of courts in recent years have ruled just the opposite and have not been persuaded that courts automatically would dismiss claims for personal liability of insurance claims adjusters for bad faith. In some cases, judges from the same states have ruled differently. For instance, the Ohio state court case of Baker discussed earlier conflicts with the ruling of Wiseman $v$. Universal Underwriters Insurance Co., ${ }^{125}$ a federal case before the United States District Court for the Southern District of Ohio. ${ }^{126}$

The underlying facts of the Wiseman case involved allegations that a motorcycle dealer negligently sold a defective motorcycle which purportedly caused an injury to a passenger. ${ }^{127}$ Both the motorcycle dealer and an employee of the motorcycle dealer were named in the lawsuit. ${ }^{128}$ The case ended up going to trial with a verdict being entered in excess of the policy limits. ${ }^{129}$ Following the verdict in excess of the policy limits, the employee of the motorcycle dealer filed claims against the dealer's insurer and a claims adjuster of the insurer alleging that the insurer and adjuster, among other things, failed to advise him of three settlement offers made within the policy limits and advise him as to any issues of exposure to personal liability. ${ }^{130}$ The insurer and insurer's employee contended that there were no cognizable claims against the insurer's employee because an independent duty of an adjuster to act in good faith with regard to settling claims against the insured did not exist. ${ }^{131}$

In analyzing the question of whether an insurance company employee claims adjuster could be held liable for bad faith, the Wiseman court noted that imposing personal liability upon an adjuster is not a "novel concept."132 The court noted that it has been doctrinally recognized in insurance law that "an insurance agent is liable for his or her own tortious conduct to the same extent

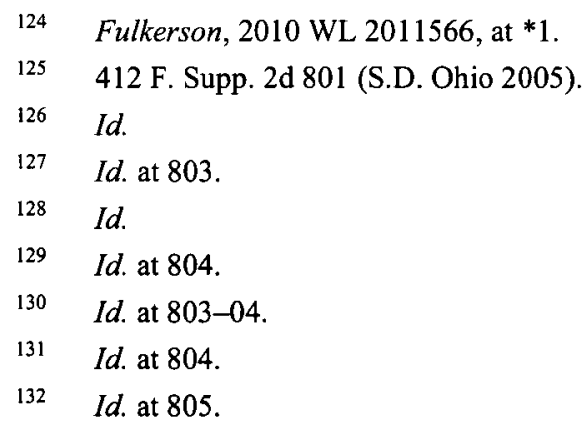


as though the agent had been acting on his or her own behalf and not as an agent."

In holding that the fraudulent joinder doctrine did not apply concerning the insurance company employee adjuster's presence as a defendant in the case, ${ }^{134}$ the Wiseman court stated that a "reasonable basis" could exist under Ohio law to recognize claims for personal liability of an insurance company employee adjuster for bad faith. ${ }^{135}$ The Wiseman court specifically noted that insurance adjusters in Ohio could be held liable for "tortious conduct including misrepresentation, negligence in failing to obtain coverage, and negligence in failing to exercise reasonable case [sic] in advising customers about the terms of coverage." ${ }^{\prime 136}$ It should be noted that all of these causes of action mentioned involve negligent conduct, not conduct which rises to the standard of recklessness or bad faith. However, it is significant that the Wiseman court did not preclude the possibility that Ohio could recognize personal liability for bad faith. Other states have not foreclosed on the possibility of such a cause of action for personal liability being recognized.

On at least four separate occasions, the United States District Court for the District of Arizona has ruled that the joinder of an insurance company employee adjuster to a lawsuit for the purposes of defeating diversity jurisdiction is not fraudulent. In 2006, the Ballesteros v. American Standard Insurance Co. of Wisconsin ${ }^{137}$ case involved allegations that a Spanishspeaking insured was not given a written offer of uninsured motorist's and underinsured motorist's insurance coverage in Spanish and that the insurer, an insurance agent, and an insurance adjuster "intentionally and wantonly" failed to do so. ${ }^{138}$ The plaintiffs also contended that the insurer engaged in this practice due to a profit motive, noting that uninsured motorists and underinsured motorists insurance coverage is not very profitable and that the employees of the insurer were compensated based on the insurer's profitability. ${ }^{139}$ Among a number of claims, the plaintiffs proffered bad-faith claims against the insurance company's employee adjuster. ${ }^{140}$

In analyzing whether the bad-faith claims against the adjuster were colorable, the Ballesteros court cited a 1984 Arizona insurance bad-faith case,

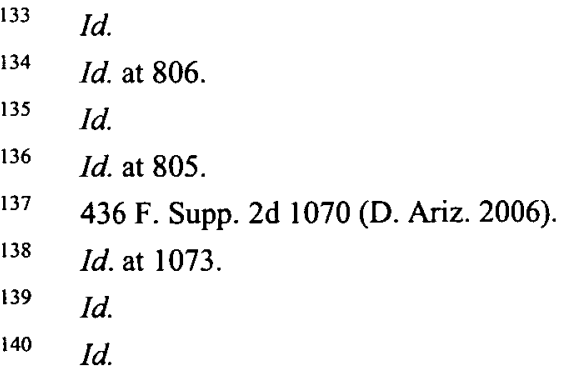


Farr v. Transamerica Occidental Life Insurance Co. of California. ${ }^{141}$ The Farr court had earlier cited a dissent by Judge Kerrigan in a 1974 California Court of Appeals case, Hale v. Farmers Insurance Exchange, ${ }^{142}$ which criticized the part of the Gruenberg decision which embraced insurance adjuster immunity from personal liability for insurance bad faith. ${ }^{143}$ The dissenting judge in the Hale decision stated the following:

[T] he Gruenberg rule protecting independent contractors from punitive damage liability makes little sense in the present context for it would mean that any employee of an insurance company who willfully and in bad faith denies a claimant payment on his policy of insurance would be insulated from the punishment of exemplary damages for his conduct. One's sense of justice cannot help but be affronted when the application of abstract legal doctrine yields such a result in practice. The Gruenberg court could not possibly have intended to insulate intentional tortfeasors from exemplary liability merely because they happen to work for an insurance carrier. $^{144}$

In including this language, the Ballesteros court concluded that it is unclear under Arizona law if a claims adjuster could be personally liable for insurance bad faith. ${ }^{145}$ Thus, the fraudulent joinder doctrine did not apply concerning the adding of the claims adjuster as a party defendant. ${ }^{146}$ Following Ballesteros, on at least three other occasions, in 2008 in Allo v. American Family Mutual Insurance Co., ${ }^{147}$ in 2010 in Wapniarski v. Allstate Insurance Co., ${ }^{148}$ and in 2012 in IDS Property Casualty Insurance Co. v. Gambrell ${ }^{149}$ the United States District Court for the District of Arizona held claim adjusters were not fraudulently joined to defeat diversity jurisdiction and expressed the belief that the personal liability question for insurance company employee claims adjusters is still unsettled.

141 Id. at 1078 (citing Farr v. Transamerica Occidental Life Ins. Co. of Cal., 699 P.2d 376, 386 (Ariz. Ct. App. 1984)).

142117 Cal. Rptr. 146 (Cal. Ct. App. 1974) (Kerrigan, J., concurring in part and dissenting in part).

143 Farr, 699 P.2d at 386 (citing Hale, 117 Cal. Rptr. at 162 (Kerrigan, J., concurring in part and dissenting in part)).

144 Hale, $117 \mathrm{Cal}$. Rptr. at 162-63 (Kerrigan, J., concurring in part and dissenting in part).

145 Ballesteros, 436 F. Supp. $2 \mathrm{~d}$ at 1079.

$146 \quad I d$.

147 No. CV-08-0961-PHX-FJM, 2008 WL 4217675, at*3 (D. Ariz. Sept. 12, 2008).

148 No. CV-10-0823-PHX-LOA, 2010 WL 2534167, at *5 (D. Ariz. June 18, 2010).

149913 F. Supp. 2d 748, 754 (D. Ariz. 2012). 
South Carolina is also among the jurisdictions where a federal district court has noted that it is unsettled as to whether a claims adjuster could incur personal liability for insurance bad faith. In Pohto v. Allstate Insurance Co., ${ }^{150}$ the plaintiff, insured under a motorcycle vehicle insurance policy, was seriously injured by a hit and run driver. ${ }^{151}$ The injured plaintiff's uninsured and underinsured motorists carrier declined to pay the full policy limits, and the insured filed a bad-faith claim against the insurer as well as the insurer's employee adjuster. ${ }^{152}$

The United States District Court for the District of South Carolina found that the insured could possibly establish a colorable cause of action based upon bad faith against the insurer's employee adjuster. ${ }^{153}$ The Pohto court particularly noted that, under South Carolina agency law, a company employee could be held personally liable for his or her own torts, even if the torts are committed when the employee is acting within his or her scope of employment. ${ }^{154}$ It thus rejected application of the contractual privity rule expressed in other cases and expressly cited the Garrison Contractors and $O$ 'Fallon decisions in holding it is possible that a cause of action could lie against an insurance company employee claims adjuster for bad faith. ${ }^{155}$

The Garrison Contractors decision has also been cited with approval by the United States Court of Appeals for the Fifth Circuit. ${ }^{156}$ In Gasch v. Hartford Accident \& Indemnity Co. ${ }^{157}$ claims based upon the common law duty of good faith and fair dealing, as well as the Texas Deceptive Trade Practices Act involving the improper denial of worker's compensation survivor death benefits, were filed against an insurer and a claims adjuster. ${ }^{158}$ The United States Court of Appeals for the Fifth Circuit upheld the reasoning of the Texas Supreme Court in the Garrison Contractors case, noting that the claims adjuster at issue in Gasch serviced insurance policies for the insurer and was "engage[d] in the business of insurance" for purposes of the Texas Unfair and Deceptive Trade Practices Act and thus could potentially incur liability as a "person."159 The United States Court of Appeals for the Fifth Circuit in Gasch distinguished the Garrison Contractors case from another Texas Supreme

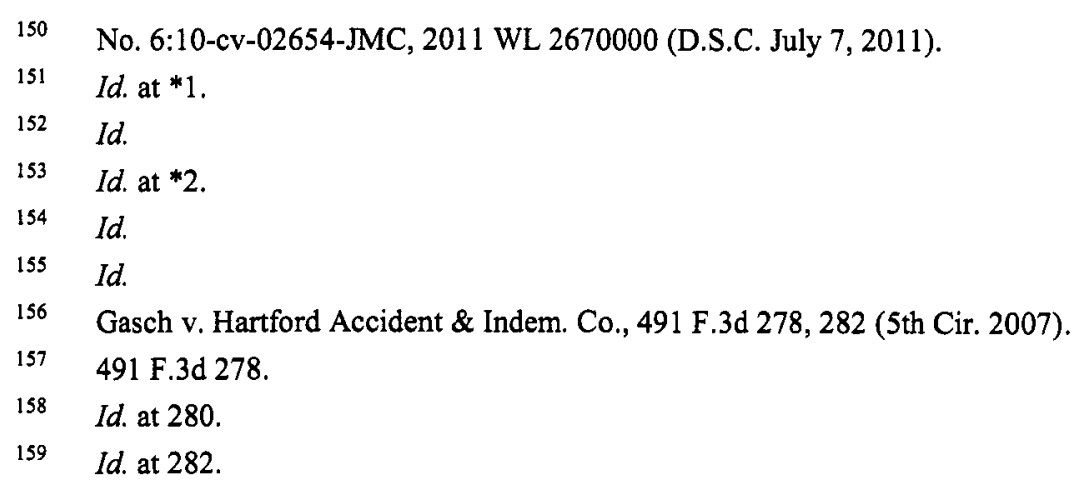


Court case, Natividad v. Alexsis, Inc., ${ }^{160}$ which held in 1994 that a claims adjuster did not owe a worker's compensation a duty of good faith and fair dealing absent a "special relationship" created by contract between the adjuster and the claimant. ${ }^{16}$ The Gasch court remarked that while the Natividad court examined the issue of personal liability through the common law claim of a breach of duty of good faith and fair dealing, it did not address a statutory claim as the Garrison Contractors court did. ${ }^{162}$ Thus, the Fifth Circuit noted that a claim against an adjuster for bad-faith conduct through the Texas Deceptive Trade Practices Act would explicitly be authorized. ${ }^{163}$

Finally, a majority of the decisions discussed relating to the personal liability of an insurance company employee adjuster for insurance bad faith are cases involving allegations of bad faith in the first-party context. However, there are third-party-bad-faith cases where the personal liability issue appears, such as the $O^{\prime} F$ allon case. Leonhardt v. Geico Casualty $\mathrm{Co}^{164}$ is one such case. ${ }^{165}$ The Leonhardt case involved a car accident in which the plaintiff recovered an $\$ 800,000$ judgment in state court. ${ }^{166}$ The insurer's policy limits toward the plaintiff were $\$ 20,000$, far below the judgment recovered. ${ }^{167}$ Following the trial in state court, in which an excess judgment was recovered, the insured driver/car owner assigned all claims against the insurer to the plaintiff. ${ }^{168}$ The plaintiff contended the insurer failed to reasonably settle the claim within the policy limits and also alleged a fraud and deceit claim. ${ }^{169}$ Both the insurer and a claims adjuster employee of the insurer were named to the lawsuit. ${ }^{170}$

In declining to apply the fraudulent joinder doctrine to prevent remand of the case from federal to state court, the United States District Court for the Middle District of Florida stated as follows:

[The insurer] fails to demonstrate clearly and convincingly that an adjuster, who undertakes to deal directly with an injured third-party claimant, commits no possibly actionable wrong against the third-party if the adjuster (1) intentionally

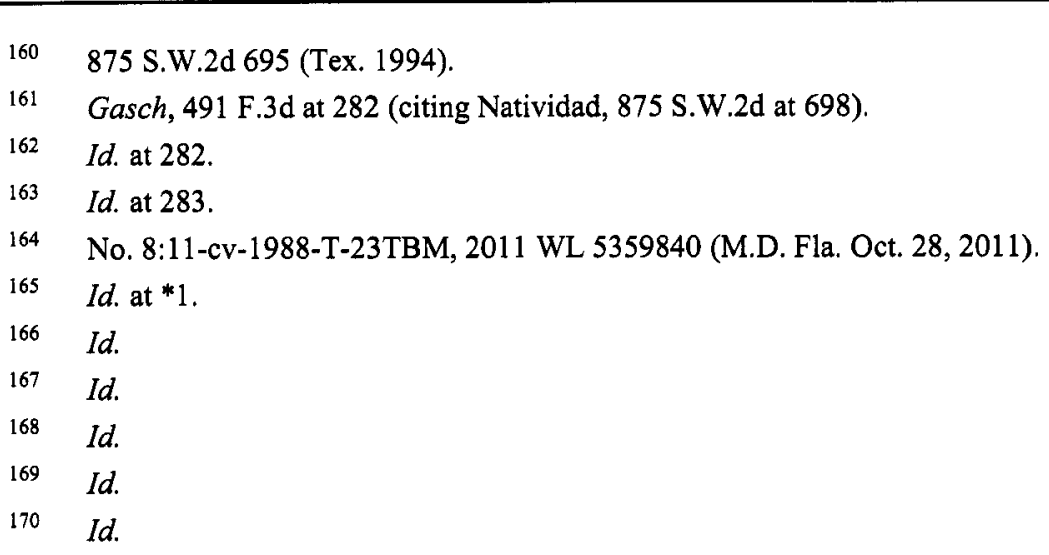


misrepresents to the third-party the amount of the damages and the amount of the available insurance coverage for a covered claim against the insured or (2) conspires with the insurer to misrepresent intentionally the amount of the available insurance coverage, in either instance with the objective of inducing the third-party (1) to rely to the third-party's detriment on the misstatement and (2) to resolve a claim for less than the amount for which the third-party otherwise would have resolved the claim if the adjuster acted in good faith. ${ }^{171}$

All of the foregoing cases demonstrate there is a growing divide in the insurance law area on the issue of whether an employee claims adjuster can be held liable for insurance bad faith. The longstanding doctrinal rule based upon the privity of contract rationale, which immunized claims adjusters from personal liability, has slowly been eroded over time.

\section{Traditional Agency Rule Relating to Contract and Tort Liability}

As the courts grapple with the doctrinal question today of whether to follow the early doctrinal rule where claims adjusters were generally held to be immune from bad-faith claims, one area of law which can be consulted for analysis of personal liability issues is the law of agency.

It is a fundamental rule concerning agency law and contract liability that "when an agent acting with actual or apparent authority makes a contract with a third party on behalf of a disclosed principal, the agent is not a party to the contract unless she and the third party agree otherwise."172 This principle was cited by the insurer and the insurer's claims adjuster in the Pohto case, where the insurer and insurer's claims adjuster also contended that no independent duties existed for the claims adjuster outside of the contract of insurance. $^{173}$

While this part of agency law would support a finding that an insurance company's employee adjuster would not incur personal liability for bad faith, other parts of agency law would support a finding of liability. While contract liability would suggest one rule, the tort liability rules would support another, as the Restatement (Third) of Agency states that "[a]n agent is subject to liability to a third party harmed by the agent's tortious conduct."174 This argument, based upon this principle of the Restatement, was cited by the insured in the Pohto case, and it was also mentioned in support of the judge's

\footnotetext{
171 Id. at $* 3$.

172 See Richard A. MANN \& BARRY S. Roberts, SMITH \& RobERSon's Business LAW 370 71 (15th ed. 2011); RESTATEMENT (THIRD) OF AGENCY $\$ 6.01$ (AM. LAW INST. 2006).

173 Pohto v. Allstate Ins. Co., C.A. No. 6:10-cv-02654-JMC, 2011 WL 2670000, at *1 (D.S.C. July 7, 2011).

174 RESTATEMENT (THIRD) OF AGENCY $§ 7.01$ (AM. LAW INST. 2006).
} 
finding that the insured could possibly have a valid cause of action against the claims adjuster for bad faith. ${ }^{175}$

Analysis of the personal liability question utilizing agency law principles alone leaves the clear divide between the argument relating to contract liability, which is one insurers and claims adjusters would utilize, and that of tort liability, which tends to support plaintiffs arguing for personal liability of adjusters to be imposed in cases of bad faith. Jurisdictions throughout the country differ on what type of cause of action bad faith really is-some states categorize it as a contract action, others a common law tort action, and others codify bad faith via state statutory mechanisms. ${ }^{176}$ Based upon the holding of at least one appellate court in Florida, the tort liability rules concerning personal liability and bad faith would never apply because Florida has a first-party bad-faith statute. ${ }^{177}$ This may very well be the case in other states which characterize first-party bad-faith claims as a statutory cause of action.

While agency law principles are helpful in analysis of whether personal liability for insurance bad faith can be imposed upon claims adjusters, the conflicting nature of agency principles applied in this situation leaves agency law incomplete to resolve issues of liability. A balance can be achieved by adoption of a doctrinal rule which imposes bad-faith liability in more egregious instances of misconduct by an insurance company's employee adjuster, but yet retains immunity from personal liability in cases lacking a "purposeful" or "actual malicious" intention on the part of the adjuster.

\section{PROPOSAL FOR BAD FAITH LIABILITY FOR INSURANCE COMPANY EMPLOYEE ADJUSTERS}

Imagine this hypothetical scenario: an insured has a valid first-party property damage claim under their homeowner's insurance policy as a result of weather-related damage. The insured lives in a state characterized by humid weather, and there is a visible leak in the roof. The claims adjuster assigned to the claim happens to be a personal rival of the insured (unbeknownst to the insured), and even though there is a personal jealousy, the adjuster declines to notify his or her employer about the conflict. The adjuster inspects the damage and vastly underreports the loss intentionally. Then, the claims adjuster takes an affirmative step of action by wrongfully notifying the insured that part of the

\footnotetext{
175 Pohto, 2011 WL 2670000, at *2.

176 See Dennis Wall, Litigation and PreVention of Insurer Bad Faith § 9:12-15 (3d ed. 2011).
}

177 Citizens Prop. Ins. Corp. v. Garfinkel, 25 So. 3d 62, 68-69 (Fla. Dist. Ct. App. 2009) ("[F]irst-party bad faith causes of action now exist in Florida not because they are torts, but because they are a statutory cause of action. Accordingly, a first-party bad faith claim cannot be wedged into the statutory exception for willful torts because it is not a tort of any variety."). 
damage is not covered. And the adjuster waits and waits and waits for days and days and then several weeks, essentially neglecting the claim due to the personal vendetta. After several weeks, mold damage becomes present. The insured has a possible first-party insurance bad-faith claim.

Arguably, the adjuster in this hypothetical scenario has acted in a purposeful and potentially malicious way. Such hypothetical purposeful and malicious behavior arguably would not only be an infringement of the terms and conditions of the policy of insurance issued to the insured, but also in contravention of the spirit of the contract. ${ }^{178}$ As courts $^{179}$ and commentators ${ }^{180}$ have noted, the operation of the insurance contract is not merely a simple contract, but an instrument which gives an insured peace of mind that not all is

178 See James M. Fischer, Why Are Insurance Contracts Subject to Special Rules of Interpretation?: Text Versus Context, 24 ARIz. ST. L.J. 995, 1034 (1992) ("The non-commercial aspect of a contractual relationship is the expectation that each party will honor and perform those obligations expressly embodied within the contractual agreement. If performance is not forthcoming, the disappointed party may suffer mental distress separate and apart from any economic loss occasioned by the breach. The general rule is that emotional distress damages are not available for breach of contract. In limited circumstances, however, where emotional distress is particularly likely, courts have awarded such damages. In cases involving an insurer's breach of the insurance contract, emotional distress damages are the norm.").

179 See, e.g., Ingalls v. Paul Revere Life Ins. Grp., 561 N.W.2d 273, 283 (N.D. 1997) ("Because a primary consideration in purchasing insurance is the peace of mind and security it will provide, an insured may recover for any emotional distress resulting from an insurer's bad faith."); McCorkle v. Great Atlantic Ins. Co., 637 P.2d 583, 588 (Okla. 1981) ("We believe that the purchaser of insurance does not contract to obtain a commercial advantage but to protect himself/herself against the risks of accidental losses and the mental stress which could result from such losses. Therefore, we think one of the primary reasons a consumer purchasers any type of insurance (and the insurance industry knows this) is the peace of mind and security that it provides in the event of loss.").

180 See Jay M. Feinman, The Law of Insurance Claims Practices: Beyond Bad Faith, 47 TORT TRIAL \& INS. PRAC. L.J. 693, 711 (2012). Professor Feinman states the following:

The individual insurance relation bears a promise of security, and each individual relation is an instance of the process of providing collective security through insurance. The purpose of insurance is to ameliorate the financial consequences of risk by transferring the risk from an individual to a group and sharing the cost of the risks that come to pass among the members of the group. More broadly, insurance provides a social safety net for individuals and businesses. Most Americans are only a car accident, a fire in the home, a lawsuit, or an injury away from having the wealth, the comfort, and the lifestyle accumulated over a lifetime of work wiped out. Insurance does not remove all of the consequences of a catastrophic loss, but it can make it something other than a catastrophe.

The promise of security has two dimensions. Insurance provides the insured peace of mind by promising security in the event of future losses ....

Id.; see also Jeffrey E. Thomas, Crisci v. Security Insurance Co.: The Dawn of the Modern Era of Insurance: Bad Faith and Emotional Distress Damages, 2 NEV. L.J. 415, 441 (2002) ("Insurance policies are purchased in significant part to obtain 'peace of mind.' When an insurer acts in bad faith to deprive a policyholder of benefits due under a policy, emotional distress is foreseeable and, in many cases, likely."). 
financially lost when covered perils occur. Upon first glance in this hypothetical case, without any application of law or doctrinal legal rules, one might be inclined to impose liability upon the claims adjuster for bad-faith conduct.

However, take another hypothetical example-what if the claims adjuster is assigned to a property damage claim? A hypothetical state statute mandates that the claims adjuster inspect the property damage within ten days of the claim being submitted. For reasons outside of any purposeful or malicious conduct, the adjuster happens to inspect the property damage on the 11 th day. The claim is paid in full on the 13 th day, with no other potential badfaith issues present. Technically, the adjuster has violated the hypothetical statute due to the lateness in inspection of the property damage. Such lateness may be defined as an unfair claims handling practice, which can potentially expose a claims adjuster to liability. However, the doctrinal rules which have emerged concerning bad faith generally would consider such negligent noncompliance to be outside of the scope of a bad-faith scenario, as it arguably does not rise to the level of "reckless" conduct. ${ }^{181}$ In this other example, one might have the inclination to not impose personal liability upon the claims adjuster for the negligent noncompliance with the statute.

Both of these hypothetical scenarios can result in a situation where one's initial inclination on liability may not be the actual outcome depending upon whether the state follows the early doctrinal rule immunizing claims adjusters from liability or is one that has questioned it.

To balance the competing arguments concerning insurance company employee adjuster liability for insurance bad faith, I propose the following: if a trial court makes an evidentiary finding that an insurance company employee claims adjuster acts with the purposeful or actual malicious intention (not knowing, reckless, or negligent intention) to prejudice the rights of an insured, then that claims adjuster would be subject to bad-faith liability.

Such a rule would reserve the application of bad-faith liability upon an adjuster to cases of apparent misconduct. In the area of criminal law, the Model Penal Code's definition of "purposely" provides guidance in determining which particular situations could result in bad faith-liability. "Purposely," in the Model Penal Code, would encompass situations where a person acts intending a certain result to follow. ${ }^{182}$ In the world of insurance bad faith, this would

181 See Chad G. Marzen, Crop Insurance Bad Faith: Protection for America's Farmers, 46 CREIGHTON L. REV. 619, 630-31 (2013) ("[I]f an insurer acts recklessly and/or intentionally in disregard of the rights of an insured policyholder, or completely lacks a reasonable basis for denying a claim, then states that recognize first-party insurance bad faith claims may find an insurer liable in tort.").

182 See Model Penal CODE $\$ 2.02(2)$ (a) (AM. LAW INST. 1962).

(a) Purposely. A person acts purposely with respect to a material element of the offense when: (i) if the element involves the nature of his conduct or a result thereof, it is his conscious object to engage in conduct of that nature or 
encompass a situation where an employee adjuster acts in such a fashion where his or her purposeful intention would be to prejudice the rights of an insured.

In addition, liability would also be imposed under this rule in cases where a trial court finds that an employee adjuster acted with an actual malicious intention. ${ }^{183}$ Outside of personal liability issues for bad faith, a finding of an actual malice will support punitive damages awards in numerous states. ${ }^{184}$

A critique of this rule will likely be that a claims adjuster still does not owe any duty to the insured that is independent of the insurance contract between the insurance company and the insured. A recent California insurance case, Bock v. Hansen, ${ }^{185}$ questions the argument that there is a lack of any duty between a claims adjuster and insured. ${ }^{186}$ The underlying facts of the Bock case involved questions concerning an insurance adjuster's conduct in adjusting a property loss when a tree limb crashed into the insureds' home. ${ }^{187}$ The adjuster at issue allegedly represented that cleanup costs were not covered under the applicable insurance policy, ${ }^{188}$ altered the scene of the damage before taking photographs, ${ }^{189}$ and also allegedly submitted false claim reports. ${ }^{190}$ Among a number of claims, the insureds filed a negligent misrepresentation claim against the adjuster. ${ }^{191}$ The adjuster moved to dismiss the negligent misrepresentation claim and the other claims. ${ }^{192}$

to cause such a result; and (ii) if the element involves the attendant circumstances, he is aware of the existence of such circumstances or he believes or hopes that they exist.

Id.

183 For instance, the South Dakota Supreme Court has defined "actual malice" as "a positive state of mind, evidenced by the positive desire and intention to injure another, actuated by hatred or ill-will towards that person." Isaac v. State Farm Mut. Auto. Ins. Co., 522 N.W.2d 752, 761 (S.D. 1994).

184 See Michael L. Rustad, The Closing of Punitive Damages' Iron Cage, 38 LoY. L.A. L. REV. 1297, 1325-26 (2005) ("A large number of states have enacted statutes that specify the state of mind required for punitive damages. In general, the culpability leading to punitive damages varies from gross negligence in some states to actual malice in others. The trend in the law is toward increasing the standard of conduct required for punitive damages. The range of the defendant's culpability varies from gross negligence to the predicate of actual malice; no jurisdiction permits the recovery of punitive damages for mere negligence.").

185170 Cal. Rptr. 3d 293 (Cal. Ct. App. 2014).

$186 \quad$ Id. at 296.

$187 \quad I d$.

$188 \quad I d$ at $296-97$.

189 Id.

$190 \quad$ Id. at 300.

191 Id.

192 Id. 
In holding that the insureds could pursue a negligent misrepresentation claim to hold the claims adjuster personally liable, the Bock court noted that the relationship between an insurer and insured is a "special relationship." "193 The Bock court cited ${ }^{194}$ a California Supreme Court decision, Vu v. Prudential Property \& Casualty Insurance Co., ${ }^{195}$ which noted that the relationship between an insurer and insured, while not a true fiduciary relationship, creates special, elevated duties on the part of an insurer due to the unique nature of an insurance contract. ${ }^{196}$

The Bock court held that "[s]uch special relationship leads to the conclusion that [the claims adjuster], the employee of the party in the special relationship, had a duty to the [insureds]. Likewise, the general law of negligent misrepresentation applies." 197 While it is unclear whether the Bock court would extend its holding to cover a claim based upon insurance bad faith, Bock is significant in stating that an insurance company employee adjuster is in a situation where they hold a "special relationship" with the insured.

The imposition of a personal duty upon insurance company employee claims adjusters is also supported by an analogous situation with cases involving the breach of warranty of fitness for a particular purpose. In commercial transactions for the sale of goods, an implied warranty of fitness for a particular purpose arises when a seller knows a buyer is purchasing goods for use in a specified purpose, and the buyer then also relies upon the seller's expertise in guiding the selection of suitable goods for the buyer's particular purpose. $^{198}$ In the case of an implied warranty of fitness for a particular purpose, the buyer is relying upon the particular knowledge and expertise of the

\footnotetext{
193 Id. at 303 (citations omitted).

$194 I d$.

19533 P.3d 487 (Cal. 2001). The Supreme Court of California stated:

The insurer-insured relationship, however, is not a true 'fiduciary relationship' in the same sense as the relationship between trustee and beneficiary, or attorney and client. It is, rather, a relationship often characterized by unequal bargaining power in which the insured must depend upon the good faith and performance of the insurer. This characteristic has led the courts to impose 'special and heightened' duties.
}

Id. at 492 (citations omitted).

196 Id. at 491-92.

197 Bock, 170 Cal. Rptr. 3d at 303.

198 See MANN \& ROBERTS, supra note 172, at 449 ("The implied warranty of fitness for a particular purpose arises if at the time of sale the seller had reason to know the buyer's particular purpose and that the buyer was relying upon the seller's skill and judgment to select suitable goods."); see also J.W. Looney, Warranties in Livestock, Feed, Seed, and Pesticide Transactions, 25 U. MEM. L. REV. 1123, 1128 (1995) ("The second implied warranty arising in a sales transaction is that the goods are fit for a particular purpose. This warranty is made when the seller has reason to know of a particular purpose for which the buyer is purchasing the goods and when the buyer is relying on the skill or judgment of the seller to select or furnish suitable goods."). 
seller in guiding their decision-making as to a purchase. In essence, the buyer is placing his or her trust and confidence in the seller to guide them to the right decision. They have placed their questions in the seller's hands.

The relationship between insurance adjuster-insured is similar in an important respect. To note, one key difference is that, in one case, the sale of goods is involved, and the other does not involve the sale of goods, but rather questions under an insurance contract. But in both the case of an implied warranty of fitness for a particular purpose and the relationship between an insurance adjuster-insured, the insured has placed their trust and confidence in the insurance adjuster to guide them to the right decision pursuant to the terms and conditions of an insurance contract. While the buyer is looking at the purchase of goods, the insured in many cases has suffered a loss of goods or property and is placing their questions in the insurance adjuster's hands. Because of this disparity, it is arguable that an insurance adjuster should certainly have at least some sort of heightened duty to the insured. A rule imposing personal liability upon insurance company employee claims adjusters for purposeful or malicious bad faith may very well deter such behavior and promote the integrity and spirit of the insurance claims process. At the same time, the rule is not so sweeping to include situations where an adjuster was simply negligent or forgetful - the traditional rule concerning immunity for bad-faith liability would still apply.

\section{CONCLUSION}

Courts throughout the United States consistently face many difficult questions of insurance law. Whether it be insurance policy coverage questions or questions concerning bad faith, there is no shortage of insurance cases for courts to compare, comprehend, and consider. In the area of bad-faith jurisprudence, a growing question is whether or not an insurance company employee claims adjuster can be held liable for insurance bad faith. While the traditional rule is that insurance company employee claims adjusters are immune from personal liability for bad faith, a growing number of courts are adopting an emerging minority position imposing personal liability.

As the question of personal liability for bad faith by insurance company employee adjusters remains unsettled, courts can adopt a sensible rule: if a trial court makes an evidentiary finding that an insurance company employee claims adjuster acts with the purposeful or actual malicious intention (not knowing, reckless, or negligent intention) to prejudice the rights of an insured, then that claims adjuster would be subject to bad-faith liability. As more courts examine this question in the future, courts should not impose personal liability in all cases involving adjusters, but rather just the more egregious cases of bad faith where purposeful or actual malicious intention is present. 